\title{
Endoscopic Approach to Cavernous Sinus Aneurysm
}

\section{Kavernöz Sinüs Anevrizmasına Endoskopik Yaklaşım}

Savas CEYLAN ${ }^{1}$, Ihsan ANIK ${ }^{1}$, Kenan $\mathrm{KOC}^{1}$, Ercument CIFTCI $^{2}$, Burak CABUK ${ }^{1}$

${ }^{1}$ Kocaeli University, Pituitary Research Centre, Department of Neurosurgery, Kocaeli, Turkey

${ }^{2}$ Kocaeli University, Faculty of Medicine, Department of Radiology, Kocaeli, Turkey

Corresponding Author: Savas CEYLAN / E-mail: ssceylan@yahoo.com

\begin{abstract}
Aneurysms protruding into sellae may mimic pituitary tumors by compressing adjacent cranial nerves. Carotid-Cavernous aneurysms are rarely associated with mortality, and surgical intervention is recommended especially for neuro-ophthalmologic progression. In this report we presented a 51-year-old woman who had severe headache and neuro-ophthalmologic signs with the initial diagnosis of pituitary apoplexy on MRI (Magnetic Resonanse Imaging). However preoperative CTA (Computed Tomography Angiography) revealed a carotid cavernous aneurysm protruding into sellae. The patient underwent endovascular intervention and endoscopic transphenoidal approach for the removal of the hematoma compressing the cranial nerves. The patient's neuro-ophthalmologic symptoms were improved during the follow-up, which may be related due to rapid evacuation of the hematoma.
\end{abstract}

KEYWORDS: Endoscope, Cavernous sinus, Aneurysm, Transphenoidal approach

öz

Sellar bölgeye protrude olan anevrizmalar kranyel sinirlere bası oluşturarak hipofiz tümörlerini taklit edebilirler. Karotid kavernöz anevrizmalar nadiren mortaliteye neden olurlar ve cerrahi girişim özellikle nörooftalmolojik progresyon gösteren olgularda önerilir. Bu yazıda, elli-bir yaşında bayan, ilk tanısı MRG'de (Magnetik Rezonans Görüntüleme) pitüiter apopleksi olan fakat preoperatif BTA (Bilgisayarlı Tomografi Anjiyografi) sonrası sella içine protrude olan karotid kavernöz anevrizma saptanan semptom ve bulgularında şiddetli başağrısı ve görme bozukluğu olan hasta sunulmuştur. Hastaya endovasküler girişim sonrası kranyel sinir basısına neden olan hematomun boşaltılması için endoskopik transsfenoidal girişim uygulanmıştır. Hastanın nöro-oftalmolojik semptomları takip süresi içinde gerilemiştir. Bu durumun hematomun hızıı bir şekilde boşaltılmasına bağlı olabileceği düşünülmüştür.

ANAHTAR SÖZCÜKLER: Endoskop, Kavernöz sinüs, Anevrizma, Transsfenoidal yaklaşım

\section{INTRODUCTION}

Neuro-ophthalmological signs are the most common reason for the treatment of carotid cavernous aneurysms (CCA). The risk for subarachnoid hemorrhage and for other major neurological morbidity has been reported to be low $(6,8)$.

In this report we present a 51- year-old woman with the symptoms of left total ophthalmoplegia and severe headache. Pituitary apoplexy was the initial diagnosis with Magnetic Resonance Imaging (MRI). However computed tomography angiography (CTA) and digital angiography (DSA) revealed a partially thrombotic aneurysm of the left internal carotid artery (ICA) cavernous segment that protruded into the sellae. Ptosis, and the medial and upper ocular movements of the patient were improved during the three months follow-up after pipeline stent placement, coil embolization and balloon placement and removal of hematoma by the endoscopic transphenoidal approach.

\section{CASE REPORT}

A 51-year-old woman was admitted with left ptosis and severe headache for one day. Neurological examination revealed left total ophthalmoplegia (Figure 1A). Cranial MRI demonstrated hemorrhagic intrasellar lesion (Figure 2A).
Surgery was planned for the diagnosis of pituitary apoplexy. CTA was performed and left ICA cavernous segment aneurysm was detected. On DSA, carotid cavernous segment partially thrombotic aneurysm with $30 \times 18 \times 20 \mathrm{~mm}$ dimensions that protruded into the sella was seen (Figure 2B). Clopidogrel was started before procedure. The patient was treated under general anesthesia. The procedure was performed through $6 \mathrm{~F}$ and $8 \mathrm{~F}$ femoral artery accesses. Following arterial access, the patient was administered intravenous heparin to achieve optimal clotting time. An 8F guiding-catheter was placed into the distal cervical ICA. Cerebral angiography including rotational angiography was performed. A semithrombosed giant cavernous ICA aneurysm with large and irregular neck was detected. The use of a flow diverting stent system was planned. The aneurysm neck could not passed with standard microcatheter and microwire for flow diverting stent. For this reason parent artery occlusion was considered as a treatment option. Balloon occlusion test was performed and patient passed the test. Proximal occlusion was performed with detachable balloon and detachable coils. Since aneurysm was filled with retrograde flow, distal occlusion of parent artery was performed with detachable coils via vertebral arteryposterior communicating artery route. Control angiography showed no aneurysmal filling (Figure 2C). 
After neuroradiologic intervention, we used the recently defined endoscopic transphenoidal cavernous sinus (binostril) approach to remove the hematoma (1-4).

Left paramedian sellar floor opening was performed and expanded laterally with the aid of mini-doppler and navigation. After opening of the dura and removal of the hematoma in the sellar region, the endoscope was advanced through the aneurysm dome localized in the cavernous sinus (Figure 2D). We removed the coagulated hematoma with the help of curettes and aspirator. There were no surgical complications. Ptosis, medial and upper ocular movements of the patient were improved during the three months followup (Figure 1B).

\section{DISCUSSION}

Sellar aneurysms may mimic pituitary tumors by compressing adjacent cranial nerves (7). MRI is the advanced diagnostic procedure in the preoperative assessment of patients with sellar lesions (7). However CTA, which is easier to perform than DSA, may be useful to avoid misdiagnosis in patients with pituitary apoplexy. DSA should also be performed if a vascular lesion was detected on CTA.

Aneurysms arising from the cavernous segment of ICA are rarely associated with life-threatening complications (8). CCA may cause neurological deficits, primarily related to vision including progressive ophthalmoplegia, persistent diplopia, severe trigeminal nerve pain, erosion of the wall of the sphenoid sinus, or a carotid-cavernous fistula, which are the reasons of recommendation for therapy $(5,6)$.

Stiebel-Kalish et al (8) compared the neuroophthalmologic results of 189 aneurysm patients who underwent longterm follow-up, 74 were treated endovascularly and 115 were followed conservatively. In their study, pain resolved or improved in the majority of treated patients even after adjusting for initial severity of pain and spontaneously resolved or improved in $56 \%$ in the group of patients selected for follow-up without intervention. However the treatment did not significantly improve the patients' final diplopia after adjusting for their initial diplopia. They concluded that endovascular treatment of carotid cavernous aneurysms leads to a significantly higher rate of pain resolution compared with untreated patients, even after adjusting for initial pain severity and diplopia that may not resolve after treatment (8).

In our patient, ptosis, medial and upper ocular movements of the patient were improved during the three months follow-up. Our decision for the removal of hematoma after embolization was based on the early determined neurologic symptoms of the patient and rapid embolization. Thus, the patient had a chance of improvement of the symptoms with the relief of cranial nerve compression. Endoscopic transphenoidal cavernous sinus approaches can be applicable gaining experience in endoscopic transphenoidal approach (3). This technique provides minimally invasive approach to the cavernous sinus, which is difficult to reach this area by the other skull-base procedures (3).

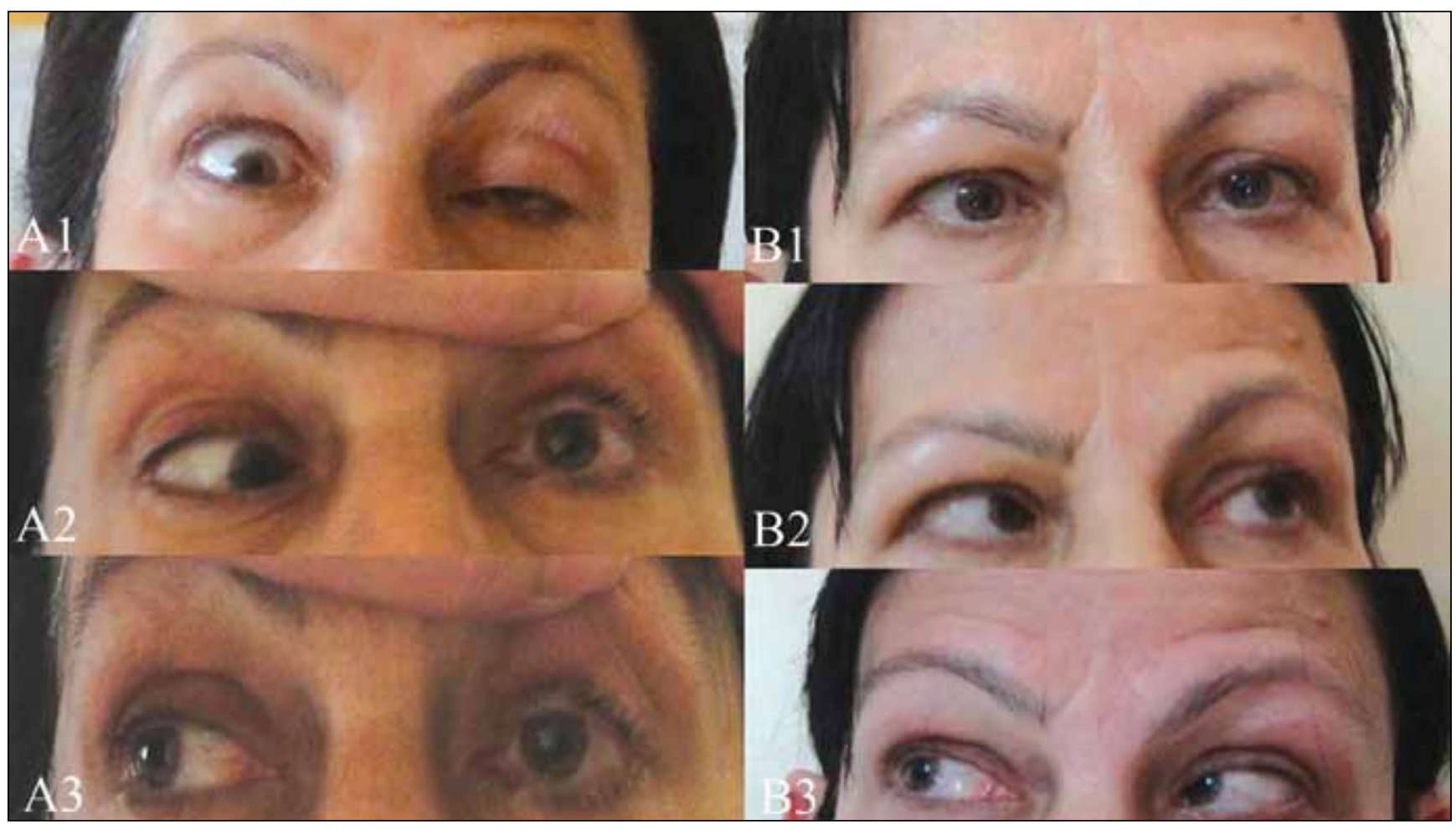

Figure 1: A(1-3): Preoperative neurological examination of the patient. The signs of the left total ophtalmoplegia. B (1-3): Postoperative 3rd month neurological examination of the patient (Ocular movements). The symptoms of the patient progressed during follow-up. 


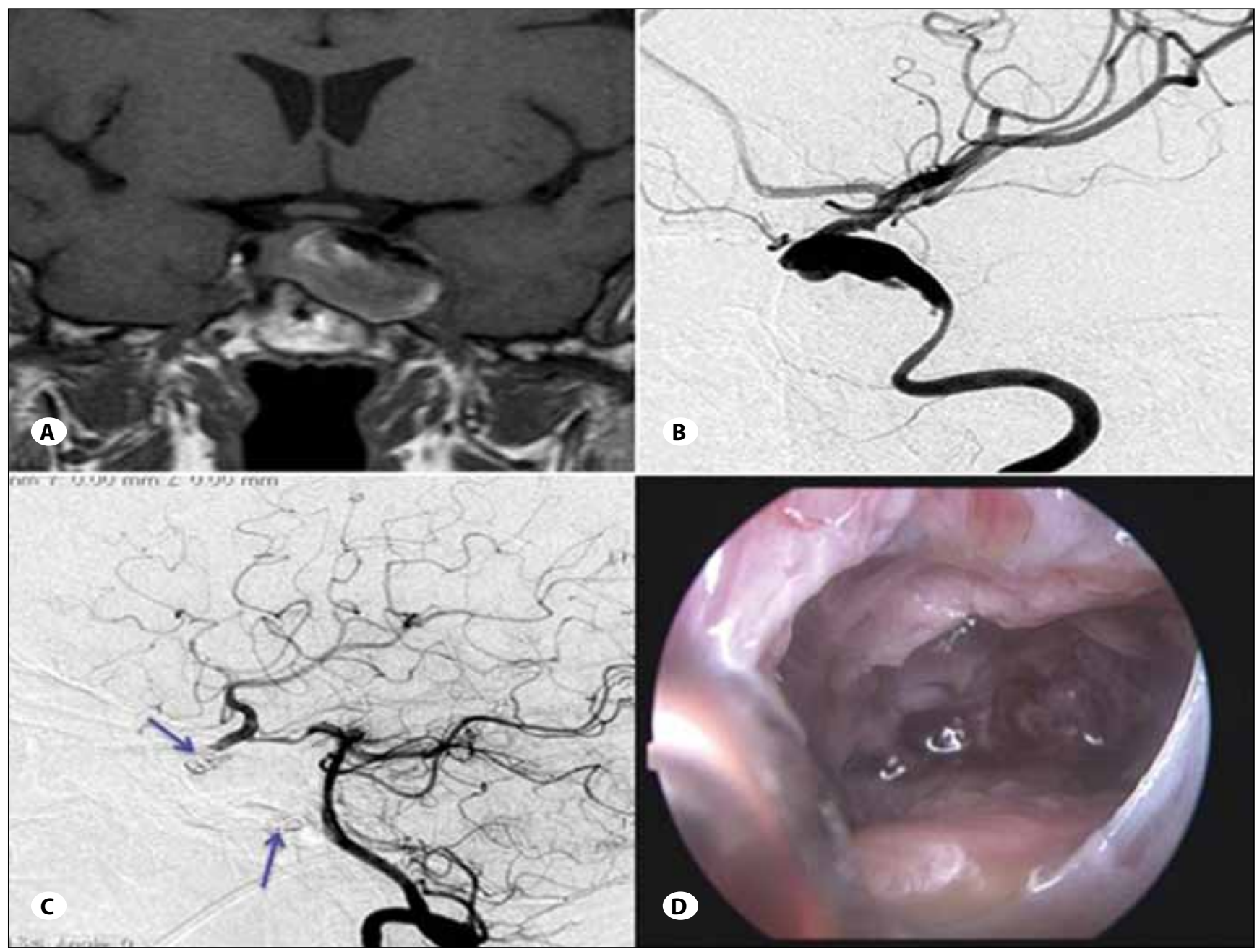

Figure 2: A) T1-weighted coronal MRI of the patient shows hemorrhagic content lesion fulfilling and expanding the sella. Note that the left ICA wall is irregular. B) Preoperative DSA of the patient reveals left thrombosed cavernous sinus aneurysm protruding into the sella. C) Postoperative DSA of the patient demonstrates proximal coil embolization and balloon and distal coil embolization (blue arrows). D) Endoscopic view of the inside of the aneurysm dome is seen.

\section{CONCLUSION}

In selected cases, evacuation of hematoma via endoscopic transphenoidal approach after stabilization of CCA by endovascular treatment may provide rapid improvement of neurologic symptoms of the patients.

\section{REFERENCES}

1. Alfieri A, Jho HD: Endoscopic endonasal approaches to the cavernous sinus: Surgical approaches. Neurosurgery 9: 354- 362, 2001

2. Cavallo LM, Cappabianca P, Galzio R, laconetta G, de Divitiis E, Tschabitscher M: Endoscopic transnasal approach to the cavernous sinus versus transcranial route: Anatomic study. Neurosurgery 56: 379-389, 2005

3. Frank G, Pasquini E: Endoscopic endonasal cavernous sinus surgery, with special reference to pituitary adenomas. Front Horm Res 34:64-82, 2006
4. Ceylan S, Koc K, Anik I: Endoscopic endonasal transsphenoidal approach for pituitary adenomas invading the cavernous sinus. J Neurosurg 112(1):99-107, Erratum in (2010) J Neurosurg 112(1):210, 2010

5. Goldenberg-Cohen N, Curry C, Miller NR, Tamargo RJ, Murphy KP: Long term visual and neurological prognosis in patients with treated and untreated cavernous sinus aneurysms. J Neurol Neurosurg Psychiatry 75(6):863-867, 2004

6. Kupersmith MJ, Hurst R, Berenstein A, Choi IS, Jafar J, Ransohoff J: The benign course of cavernous carotid artery aneurysms. J Neurosurg 77(5):690-693, 1992

7. Romano A, Chibbaro S, Marsella M, Ippolito S, Benericetti E: Carotid cavernous aneurysm presenting as pituitary apoplexy. J Clin Neurosci 13(4):476-479, 2006

8. Stiebel-Kalish $H$, Kalish $Y$, Bar-On $R H$, Setton $A$, Niimi $Y$, Berenstein A, Kupersmith MJ: Presentation, natural history, and management of carotid cavernous aneurysms. Neurosurgery 57(5):850-857, 2005 